\title{
Online Learning in the Face of COVID-19 Pandemic: Assessment of Students' Satisfaction at Chitwan Medical College of Nepal Sharma K, ${ }^{1}$ Deo G, ${ }^{2}$ Timalsina $\mathrm{S},{ }^{3}$ Joshi A, ${ }^{1}$ Shrestha $\mathrm{N},{ }^{4}$ Neupane $\mathrm{HC}^{5}$
}

\author{
${ }^{1}$ School of Nursing, \\ ${ }^{2}$ Department of Anesthesia, \\ ${ }^{3}$ Research Unit, \\ ${ }^{4}$ Department of Community Medicine, \\ ${ }^{5}$ Department of Surgery, \\ Chitwan Medical College, \\ Bharatpur, Nepal.
}

\section{Corresponding Author}

Kalpana Sharma

School of Nursing,

Chitwan Medical College,

Bharatpur, Nepal.

E-mail: sharma.kalpana@cmc.edu.np

\section{Citation}

Sharma K, Deo G, Timalsina S, Joshi A, Shrestha N, Neupane HC. Online Learning in the Face of COVID-19 Pandemic: Assessment of Students' Satisfaction at Chitwan Medical College, Nepal. Kathmandu Univ Med J. 2020;COVID-19 Special Issue 70(2):40-7.

\section{ABSTRACT}

\section{Background}

Online learning can play a vital role in the process of teaching and learning during Corona Virus Disease 2019 (COVID-19) pandemic. However, learners' satisfaction is extremely important in effective implementation of the online learning, especially at institutions where it is newly adopted.

\section{Objective}

To assess satisfaction towards online learning and its predictors among students at Chitwan Medical College, Bharatpur.

\section{Method}

A web-based cross-sectional survey was undertaken among 434 undergraduate and postgraduate students from various academic programs who had participated in the online classes started during this COVID-19 pandemic. A structured questionnaire consisting of 31 items (5-point Likert scale) covering four major student satisfaction domains (learners' dimensions, technological characteristics, instructors' characteristics and course management and coordination) was distributed to the students using Google Form.

\section{Result}

More than half $(53.5 \%)$ of the students were satisfied with the online learning, while $29.7 \%$ gave neutral views. Bivariate analyses found that all four domains scores were positively correlated with each other as well as with the students' overall satisfaction towards learning. In multivariate analysis, female gender [aOR: $2.72, p=0.013$ ], WiFi as internet modality for learning [aOR: $3.36, p=0.001$ ) and learners' dimension score [aOR: $1.27, p<0.001$ ] were the significant predictors of students' satisfaction.

\section{Conclusion}

Although recently adopted, the satisfaction of the students towards online classes appears good, and prioritizing the identified predictors and working on the weak links could assist in enhancing students' satisfaction and better outcomes.

\section{KEY WORDS}

COVID-19 pandemic, Learners' satisfaction, Online learning 


\section{INTRODUCTION}

Corona Virus Disease 2019 (COVID-19), that started from Wuhan, China gained pandemic status on March 12, $2020 .{ }^{1}$ The Government of Nepal decided to enforce countrywide lockdown since March 24, 2020 in order to curtail the spread of the corona virus. ${ }^{2}$ Since then, the lockdown has been extended several times and, has deleteriously affected several sectors including education. The pandemic has led to disruption in teaching/learning activities globally. The medical schools have not been spared either, with concerns about academic continuity and maintenance of efficiency of the health care system. ${ }^{3}$ Consequently; several medical institutions worldwide have been trying to adopt innovative technology enabled online learning as core method of teaching by making use of applications such as Zoom, Google Classroom and Google Docs among many others. ${ }^{4,5}$

Evidences show that online learning can play the role of catalyst for active learning, enhancing creativity, motivation for learning and updating existing body of knowledge and communication. ${ }^{6,7}$ The transformation from traditional learning to complete web-based learning, however presents several challenges to medical educators as well as the students. ${ }^{8-10}$ Therefore, it is imperative to understand learners' satisfaction towards online learning for effective implementation of the program.

Learners', technological and instructors' characteristics along with course design and coordination significantly determine the learners' satisfaction. ${ }^{11-13}$ We started online classes for various academic programs at our medical school since April 14 2020. This study aimed at assessing the satisfaction for online learning among undergraduate and postgraduate students of our medical college and providing insights on steps necessary for further improvement.

\section{METHODS}

This cross sectional survey included $1^{\text {st }}$ and $2^{\text {nd }}$ year students of Chitwan Medical College (CMC) enrolled in various Undergraduate (UG) and Postgraduate (PG) academic programs (except for Nursing programs, where students from $3^{\text {rd }}$ and $4^{\text {th }}$ year were also included), actively involved in online learning. The UG programs included Bachelor in Medicine and Bachelor in Surgery (MBBS), Bachelor in Dental Surgery (BDS), Bachelor in Public Health (BPH), Bachelor in Pharmacy (B Pharmacy), Bachelor in Science in Nursing (B.Sc. Nsg), Bachelor in Nursing Science (BNS) and Bachelor in Medical Laboratory Technology (B.Sc. MLT). The PG programs included Masters in Nursing (MN) and Masters in Public Health (MPH). Ethical approval was obtained from Chitwan Medical College Institutional Review Committee (Ref. no: CMC-IRC 076/077-150).

A structured self-administered questionnaire was developed based on prior literature that relate to online learning and consultation with experts in the field of medical education. ${ }^{14,15}$ It consisted of four domains: Learner's dimension, Instructors' characteristics, Technological characteristics and Course management and co-ordination. Learner's dimension (9 items) measured the students' characteristics. Instructors' characteristics (9 items) measured teachers' characteristics, frequency of interaction, feedback and way of content delivery. Technological characteristics ( 7 items) measured the effectiveness of electronic media during the content delivery. Course management and co-ordination (4 items) measured the curriculum components and learning material in the learning environment. Each item of the domains was rated in 5-point Likert scale (Strongly Disagree-1, Disagree-2, Neutral-3, Agree-4, and Strongly Agree-5). There were 2 items (rated on 1 to 5 scale) at the end of the questionnaire that measured the students' overall perception on helpfulness of online classes in context with learning process and overall satisfaction toward online learning. The questionnaire was then imported into Google Forms and was piloted among 50 students of different disciplines (who were not included in the final analysis). To verify the reliability of the instrument, Cronbach's alpha was calculated using the pilot study data. One of the items in course management and co-ordination domain "I feel difficulty in understanding the course content without face to face interaction" was removed because of its' poor interitem correlation in the domain. The resultant Cronbach's alpha for the instrument was 0.89 indicating that the tool was reliable for further study.

All the eligible 577 (out of total 627 students) students were sent an email inviting them to participate in the study. The email outlined the purpose, the voluntary nature of participation and emphasized the anonymity of the respondent. It also contained a web link to the online survey form created using Google Forms. The form was made accessible to the students from June 122020 to July 11, 2020. The survey response data was collected online and was only available to the researchers in a nonidentifiable form. The data was exported to Microsoft Excel 2016 and was analyzed using IBM SPSS (Statistical Package for Social Sciences) version 20 for window.

Standard descriptive statistics was used to describe the data, utilizing mean (SD) or frequency (percentage) as appropriate. The relationship between different domain scores was expressed by Spearman's rank correlation coefficient. A multivariate logistic regression model was constructed to identify the predictors of overall satisfaction towards online classes. $P$ value $<0.05$ was considered to be statistically significant.

\section{RESULTS}

Out of the 577 eligible participants, 434 responded and completed the survey in full with a response rate of $75.2 \%$. 
The mean age of the students was 21.8 years (Range: 17 39 years). Majority of the students were females (77.6\%), belonged to nuclear family (73.3\%), and most of them lived in municipality (90.6\%). The highest proportion of the study participants were from B.Sc. Nursing Program (28.4\%) and $1^{\text {st }}$ and $2^{\text {nd }}$ academic years i.e. $36.3 \%$ and $36.3 \%$ respectively.

A significant majority of the students (85.7\%) had internet facility i.e. WiFi at their residence that they used during the online classes. The remaining $14.3 \%(n=62)$ primarily used data package from telecommunication service provider. The median number of classes per week was 16 (6 - 18). The average number of classes attended by the students per month was $40(25-50)$. [Table 1 ]

Table 1. Baseline Characteristics of the Students $(n=434)$

\begin{tabular}{|c|c|c|}
\hline Characteristics & Number & Percentage \\
\hline \multicolumn{3}{|l|}{ Sex } \\
\hline Male & 97 & 22.4 \\
\hline Female & 337 & 77.6 \\
\hline \multicolumn{3}{|l|}{ Type of family } \\
\hline Nuclear & 318 & 73.3 \\
\hline Joint & 116 & 26.7 \\
\hline \multicolumn{3}{|l|}{ Residence } \\
\hline Municipality & 393 & 90.6 \\
\hline VDC & 41 & 9.4 \\
\hline \multicolumn{3}{|l|}{ Academic Year } \\
\hline $1^{\text {st }}$ & 157 & 36.2 \\
\hline $2^{\text {nd }}$ & 158 & 36.4 \\
\hline $3^{\text {rd }}$ & 80 & 18.4 \\
\hline $4^{\text {th }}$ & 39 & 9.0 \\
\hline \multicolumn{3}{|l|}{ Programs } \\
\hline Undergraduate & 391 & 90.1 \\
\hline MBBS & 94 & 21.9 \\
\hline B.Sc. Nsg & 122 & 28.4 \\
\hline BDS & 40 & 9.3 \\
\hline BNS & 65 & 15.1 \\
\hline $\mathrm{BPH}$ & 49 & 11.4 \\
\hline B Pharm & 14 & 3.3 \\
\hline BSc MLT & 3 & 0.7 \\
\hline Post graduate & 43 & 9.9 \\
\hline $\mathrm{MN}$ & 35 & 8.1 \\
\hline $\mathrm{MPH}$ & 8 & 1.9 \\
\hline \multicolumn{3}{|c|}{ Internet accessibility (WiFi) at home or residence } \\
\hline Yes & 372 & 85.7 \\
\hline No & 62 & 14.3 \\
\hline \multicolumn{3}{|c|}{ Participation in class through } \\
\hline WIFI & 372 & 85.7 \\
\hline Data Package & 62 & 14.3 \\
\hline
\end{tabular}

\section{Online Learning Domains}

Regarding learners' dimension (domain 1), majority of the students agreed that they "need to be updated with the latest technology" (82.4\%), "online class is effective to bridge the gap of missed time period" (71.8\%), they "got enough time to study on their own", and it "enhances selfstudying habit" (61.5\%). However, considerable proportion of the students were unbiased on the statements like "I feel confident and enjoy using the online platform applications" (35.7\%), "I feel online learning is comfortable and enjoyable" (32.9\%), "I frequently interacted with other students and instructors during the courses" (28.6\%). Furthermore, nearly one third of the students showed disagreement on the statements like "I feel online learning is comfortable and enjoyable" (30.0\%), "I frequently interacted with other students and instructors during the courses" (28.6\%). [Table 2]

Regarding instructors' characteristics (domain 2), majority of the students agreed that they are satisfied with the instructors' supportiveness and responsiveness towards their questions (81.1\%), accessibility and professional behavior during the class (73.3\%) and efforts in maintaining distraction free classes (69.9\%). However, a significant proportion of the students were neutral on the statements like "I like the instructors teaching ability with the use of various communication techniques" (27.6\%) and "I am satisfied with instructors providing clear instructions about the course prior to the classes" (27.0\%). Adding further, certain proportion of the students showed disagreement on the statements like " 1 am satisfied with the instructors reviewing the topic covered in the previous sessions" (17.3\%) and "I am satisfied with the instructor pace of punctuality in starting the starting the class" (15.0\%). [Table 2]

Regarding domain 3, majority of the students agreed that online applications are easy to use (79.2\%) and internet connection strength determines the effective learning opportunity (76.3\%). However, more than one third of the students were neutral on the statements like "I feel the response time from teachers and assistants is quicker in online courses" (33.9\%). Furthermore, more than two third $(73.7 \%)$ of the students disagreed on the statements like "I feel sudden interruption in delivering the information due to technological error (internet) hinders the learning process" and $53.0 \%$ felt that "the internet charges is expensive for online learning". [Table 3]

Regarding domain 4, majority of the students agreed that they are satisfied with the ability to contact concerned department personnel via internet (67.7\%), instructions about student participation are clearly presented (65.2\%) whereas, nearly one thirds of the students were not sure on the statements like "I feel the course materials are accessible after the completion of each classes" (27.6). In addition, $19.8 \%$ of the students disagreed on the statements like "I feel the course materials are accessible after the completion of each class"[Table 3]. 
Table 2. Distribution of Responses of the Students in Learners' Dimension and Instructors' Characteristics $(n=434)$

\begin{tabular}{|c|c|c|c|c|c|c|}
\hline Statements & SD & D & $\mathbf{N}$ & A & SA & Mean (SD) \\
\hline \multicolumn{7}{|l|}{ Domain 1: Learner's Dimension } \\
\hline I feel confident and enjoy using the online platform applications & $23(5.3)$ & $66(15.2)$ & $155(35.7)$ & $161(37.1)$ & $29(6.7)$ & $3.2(0.9)$ \\
\hline $\begin{array}{l}\text { I feel students need to be trained before undergoing online learning } \\
\text { activities }\end{array}$ & $16(3.7)$ & $56(12.9)$ & $87(20.0)$ & 199 (45.9) & $76(17.5)$ & $3.6(1.0)$ \\
\hline I feel students need to be updated with the latest technology & $21(4.8)$ & $12(2.8)$ & 43 (9.9) & $212(48.8)$ & $146(33.6)$ & $4.0(0.9)$ \\
\hline $\begin{array}{l}\text { I feel online learning orients my study plan and enhances students' } \\
\text { motivation, creativity, cognitive skills and problem solving skills }\end{array}$ & $31(7.1)$ & $65(15.0)$ & $121(27.9)$ & $170(39.2)$ & $47(10.8)$ & $3.3(1.1)$ \\
\hline I feel online learning is comfortable and enjoyable & $33(7.6)$ & $97(22.4)$ & $143(32.9)$ & $126(29.0)$ & $35(8.1)$ & $3.1(1.0)$ \\
\hline $\begin{array}{l}\text { I frequently interacted with other students and instructors during } \\
\text { the courses }\end{array}$ & $31(7.1)$ & $86(19.8)$ & $124(28.6)$ & $171(39.4)$ & $22(5.1)$ & $3.1(1.0)$ \\
\hline $\begin{array}{l}\text { I got enough time to study on my own, enhancing my self-studying } \\
\text { habit }\end{array}$ & $23(5.3)$ & $44(10.1)$ & $100(23.0)$ & $211(48.6)$ & $56(12.9)$ & $3.5(1.0)$ \\
\hline $\begin{array}{l}\text { Online class is effective in bridging the gap of missed academic } \\
\text { period }\end{array}$ & $16(3.7)$ & $32(7.4)$ & $74(17.1)$ & $212(48.8)$ & $100(23.0)$ & $3.8(0.9)$ \\
\hline $\begin{array}{l}\text { The advantages of taking classes via internet outweighed the disad- } \\
\text { vantages during college lock down }\end{array}$ & 17 (3.9) & $32(7.4)$ & $101(23.3)$ & $203(46.8)$ & $81(18.7)$ & $3.7(1.0)$ \\
\hline \multicolumn{7}{|l|}{ Domain 2: Instructors' Characteristics } \\
\hline $\begin{array}{l}\text { I like the way my instructor make students feel a sense of belong- } \\
\text { ings }\end{array}$ & $15(3.5)$ & $26(6.0)$ & $111(25.6)$ & $248(57.1)$ & $34(7.8)$ & $3.6(0.8)$ \\
\hline $\begin{array}{l}\text { I feel the instructors organization and preparation for class provides } \\
\text { comfortable learning environment }\end{array}$ & $14(3.2)$ & $36(8.3)$ & $109(25.1)$ & $238(54.8)$ & $37(8.5)$ & $3.6(0.9)$ \\
\hline $\begin{array}{l}\text { I like the instructors teaching ability with the use of various com- } \\
\text { munication technique }\end{array}$ & $14(3.2)$ & $46(10.6)$ & $120(27.6)$ & $214(49.3)$ & $40(9.2)$ & $3.5(0.9)$ \\
\hline $\begin{array}{l}\text { I like when instructor emphasizes in maintaining the distraction free } \\
\text { classes }\end{array}$ & $14(3.2)$ & $21(4.8)$ & $96(22.1)$ & $245(56.5)$ & $58(13.4)$ & $3.7(0.9)$ \\
\hline $\begin{array}{l}\text { I am satisfied with instructors providing clear instructions about the } \\
\text { course prior to the classes }\end{array}$ & $12(2.8)$ & $40(9.2)$ & $117(27.0)$ & $216(49.8)$ & $49(11.3)$ & $3.6(0.9)$ \\
\hline $\begin{array}{l}\text { I am satisfied with the instructors accessibility and professional } \\
\text { behaviour during the class }\end{array}$ & $9(2.1)$ & $23(5.3)$ & $84(19.4)$ & $270(62.2)$ & 48 (11.1) & $3.7(0.8)$ \\
\hline $\begin{array}{l}\text { I am satisfied with the instructor pace of punctuality in starting the } \\
\text { starting the class }\end{array}$ & 17 (3.9) & $48(11.1)$ & 108 (24.9) & 199 (45.9) & $62(14.3)$ & $3.5(1.0)$ \\
\hline $\begin{array}{l}1 \text { am satisfied with the instructors reviewing the topic covered in } \\
\text { the previous sessions }\end{array}$ & $22(5.1)$ & $53(12.2)$ & $99(22.8)$ & $210(48.4)$ & $50(11.5)$ & $3.5(1.0)$ \\
\hline $\begin{array}{l}\text { I am satisfied with the instructors supportiveness and responsive- } \\
\text { ness towards my questions }\end{array}$ & $11(2.5)$ & $10(2.3)$ & $61(14.1)$ & $265(61.1)$ & $87(20.0)$ & $3.9(0.8)$ \\
\hline
\end{tabular}

SD-Strongly disagree D-Disagree N-Neutral A-Agree SA-Strongly Agree

Overall Domain 1 mean score (SD): 31.5 (6.3) Overall Domain 2 mean score (SD): 32.7 (5.9)

\section{Overall satisfaction with the helpfulness of online classes to the learning process}

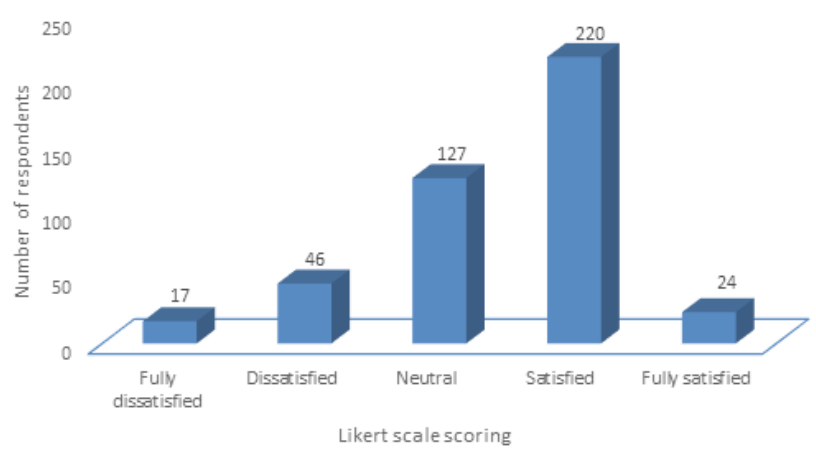

Overall satisfaction towards online classes



Figure 1. Bar Diagrams Showing Overall Satisfaction of the Students towards Online Classes $(n=434)$ 
Table 3. Distribution of Responses of the Students in Technological Characteristics and Course Management and Coordination $(n=434)$

\begin{tabular}{|c|c|c|c|c|c|c|}
\hline Statements & SD & D & $\mathbf{N}$ & A & SA & Mean (SD) \\
\hline \multicolumn{7}{|l|}{ Domain 3: Technological Characteristics } \\
\hline I feel the online applications is easy to use & $14(3.2)$ & $14(3.2)$ & $62(14.3)$ & $257(59.2)$ & $87(20.0)$ & $3.9(0.9)$ \\
\hline $\begin{array}{l}\text { I am satisfied with the quality of graphic aids such as sound and } \\
\text { picture (ppt) being displayed }\end{array}$ & $16(3.7)$ & $33(7.6)$ & $100(23.0)$ & $222(51.2)$ & $63(14.5)$ & $3.6(0.9)$ \\
\hline I feel confident that classes will not be cancelled due to weather & $107(24.7)$ & $117(27.0)$ & $109(25.1)$ & $73(16.8)$ & $28(6.5)$ & $2.5(1.2)$ \\
\hline I feel the response time from teachers is quicker in online courses & $23(5.3)$ & $67(15.4)$ & $147(33.9)$ & $169(38.9)$ & $28(6.5)$ & $3.3(1.0)$ \\
\hline $\begin{array}{l}\text { I feel internet connection strength determines our effective learn- } \\
\text { ing opportunity }\end{array}$ & $15(3.5)$ & $22(5.1)$ & $66(15.2)$ & $183(42.2)$ & $148(34.1)$ & $4.0(0.9)$ \\
\hline I feel charges to connect to the internet is expensive & $18(4.1)$ & $60(13.8)$ & $126(29.0)$ & $147(33.9)$ & $83(19.1)$ & $3.5(1.1)$ \\
\hline $\begin{array}{l}\text { I feel sudden interruption in delivering the information due to } \\
\text { technological error (internet) hinders the learning process }\end{array}$ & $24(5.5)$ & $22(5.1)$ & $68(15.7)$ & $158(36.4)$ & $162(37.3)$ & $3.9(1.1)$ \\
\hline \multicolumn{7}{|l|}{ Domain 4: Course Management and Coordination } \\
\hline I am satisfied with the content of topic covered during the classes & $14(3.2)$ & $50(11.5)$ & $92(21.2)$ & $238(54.8)$ & $40(9.2)$ & $3.5(0.9)$ \\
\hline $\begin{array}{l}\text { I feel the course materials are accessible after the completion of } \\
\text { each classes }\end{array}$ & $20(4.6)$ & $66(15.2)$ & $120(27.6)$ & $194(44.7)$ & $34(7.8)$ & $3.4(1.0)$ \\
\hline Instructions about student participation are clearly presented & $9(2.1)$ & $35(8.1)$ & $107(24.7)$ & $248(57.1)$ & $35(8.1)$ & $3.6(0.8)$ \\
\hline $\begin{array}{l}\text { I am satisfied with the ability to contact concerned department } \\
\text { personnel via internet (mail, WhatsApp's group etc.) }\end{array}$ & $17(3.9)$ & $26(6.0)$ & $97(22.4)$ & $240(55.3)$ & $54(12.4)$ & $3.7(0.9)$ \\
\hline
\end{tabular}

SD-Strongly disagree D-Disagree N-Neutral A-Agree SA-Strongly Agree

Overall Domain 1 mean score (SD): 24.8 (4.2) Overall Domain 2 mean score (SD): 14.2 (2.8)

The four domain scores had significant correlation with one another, Pearson's correlation coefficient $r$ ranging from $0.54-0.67, p<0.01$. Upon further analysis, the mean individual domain score for domains 1, 2 and 4 were significantly higher in the postgraduate students compared to total undergraduate students ( $p<0.001$ ). No significant differences were observed between the scores of different undergraduate programs.

\section{Overall Satisfaction}

Two hundred and thirty two (53.5\%) students were satisfied or fully satisfied towards the online classes being conducted. Only $16.8 \%$ ( $n=73$ ) were dissatisfied or fully dissatisfied with the online classes. The remaining $29.7 \%$ ( $n$ = 129) gave neutral scores. [fig. 1]

\section{Model of Predictors for Satisfaction towards Online Learning}

The students who were neutral regarding satisfaction towards online classes $(n=129)$ were excluded from the analysis. There were 232 participants in the satisfied group and 73 participants in the dissatisfied group. In univariate analysis, age, female gender, modality of internet facility used for online classes: WiFi, level of academia: postgraduate, individual domain scores were significantly associated with satisfaction. Place of residence, type of family, type of undergraduate program had no significant relationship with satisfaction. In multivariate analysis, female gender [aOR: 2.72, 95\% Cl: $1.23-6.02, \mathrm{p}=0.013$ ], WiFi as the internet modality users for online classes [aOR:
Table 4. Results of Multivariate Logistic Regression Analysis for Satisfaction towards Online Learning $(n=434)$

\begin{tabular}{|c|c|c|c|}
\hline Predictor Variables & $\begin{array}{l}\text { Unstan- } \\
\text { dardized } \beta\end{array}$ & aOR (95\% Cl) & p value \\
\hline Age & 0.001 & $1.00(0.88-1.14)$ & 0.992 \\
\hline $\begin{array}{l}\text { Female gender } \\
\text { Ref: Male }\end{array}$ & 1.002 & $2.72(1.23-6.02)$ & $0.013^{*}$ \\
\hline $\begin{array}{l}\text { Place of residence: Mu- } \\
\text { nicipality } \\
\text { Ref: VDC }\end{array}$ & 0.055 & $1.06(0.38-2.96)$ & 0.917 \\
\hline $\begin{array}{l}\text { Type of family: Joint } \\
\text { Ref: Nuclear }\end{array}$ & -0.061 & $0.94(0.49-1.80)$ & 0.853 \\
\hline $\begin{array}{l}\text { Internet modality used: } \\
\text { WiFi } \\
\text { Ref: Data package }\end{array}$ & 1.211 & $3.36(1.60-7.03)$ & $0.001^{*}$ \\
\hline $\begin{array}{l}\text { Academic level: Post- } \\
\text { graduate } \\
\text { Ref: Undergraduate }\end{array}$ & 1.036 & $\begin{array}{l}2.82(0.41- \\
19.33)\end{array}$ & 0.292 \\
\hline $\begin{array}{l}\text { Learners' dimension } \\
\text { (Domain 1) score }\end{array}$ & 0.239 & $1.27(1.16-1.39)$ & $<0.001^{*}$ \\
\hline $\begin{array}{l}\text { Instructors' characteris- } \\
\text { tics (Domain 2) score }\end{array}$ & 0.053 & $1.05(0.95-1.17)$ & 0.314 \\
\hline $\begin{array}{l}\text { Technological characteris- } \\
\text { tics (Domain 3) score }\end{array}$ & 0.013 & $1.01(0.89-1.15)$ & 0.832 \\
\hline $\begin{array}{l}\text { Course management and } \\
\text { co-ordination (Domain } \\
\text { 4) score }\end{array}$ & 0.017 & $1.08(0.90-1.30)$ & 0.414 \\
\hline
\end{tabular}


3.36, 95\% Cl: $1.60-7.03, \mathrm{p}=0.001)$ and learners' dimension score [aOR: $1.27,95 \% \mathrm{Cl}: 1.16-1.39, \mathrm{p}=<0.001$ ] were the significant predictors of students' satisfaction adjusted for all the other variables. The variables included in the model explained $55.2 \%$ variability in the model (Nagelkerke $R^{2}=$ 0.552) [Table 4].

Lastly, a majority (89.8\%) of the students answered that they would like to continue the online classes during this COVID-19 pandemic, when asked upon their views.

\section{DISCUSSION}

The current state of alarm due to the COVID-19 pandemic has led to abrupt changes in the education system of medical students; a shift from traditional to online learning. The use of information technology (IT) in the current situation can be a solution for educational institutions and students to continue and improve the learning process, with acquisition of new skills. However, retaining students is a greater challenging problem for on-line courses than it is for face-to-face courses. ${ }^{16}$ Hence, it has been a concern in medical education institutions in Nepal.

We found that only $53.5 \%$ of students were satisfied with online learning, with almost $30 \%$ giving neutral views. Our satisfaction rate was lower compared to other studies, where satisfaction rates as high as $93.4 \%$ have been reported. ${ }^{17,18}$ On the contrary, a systematic review has reported extremely low level of satisfaction (14.0\%) among health profession students (e.g. medicine, dentistry, pharmacy and allied medical sciences) towards online learning compared to traditional learning. ${ }^{19}$ Furthermore, Pourghaznein reported that students' satisfaction from online learning was significantly lower than lecturing and role-playing. ${ }^{20}$ The possible reasons could be that students are more familiar with the traditional learning environment and students may feel that they are generally more isolated in the virtual learning environment.

In our study, a majority (89.8\%) of the students agreed to continue online classes, quite different from studies done in Pakistan and Kuwait where they reported a lower preference $(77.0 \%$ and $51.2 \%$ respectively) for continuation of online classes in the future. ${ }^{21,22}$ This might be due to the differences in cultures of learning system and its limitations in the development of skills using lab/clinical learning environment. In addition, our students might have preferred online learning in future to prevent the calendar lag caused by the COVID-19 pandemic.

Learners' characteristics play an important role in the students' satisfaction towards online learning. Students who are updated with the appropriate technologies are able to continue their study smoothly, with greater satisfaction. ${ }^{23}$ Studies have pointed out that the students need to be updated with the latest technology to fulfil the targets of learning and needs and lack of training and technical support hindered users from making full utilization of system affecting the learner's satisfaction. . $^{24,25}$ Our students also had good agreement with the statement that "online learning provides them enough time to selfstudy and enhancing their self-studying habit". Liaw et al. also reported a close relationship between learning at one's own pace and students' satisfaction towards the learning process. ${ }^{26}$

Majority of our students agreed that they were satisfied with the instructors' supportiveness, professional behaviour and efforts in maintaining distraction free classes. A study in Bangladesh showed that the teachers' performance significantly influences the students' satisfaction in online platform. ${ }^{27}$ Likewise, Goh et al. concluded that interaction with instructors is positively related to learning outcome and satisfaction. ${ }^{28}$ Similarly, access to technology is one of the most important factors influencing student satisfaction. ${ }^{29}$ Evidences also showed that better quality of internet, proper availability of technical assistance and quality of online program positively influence students' satisfaction towards e-learning. ${ }^{30,31}$ In our study, the provision of WiFi as learning modality (which indirectly means better internet compared to data packages in Nepal) is one of the strongest predictors of students' satisfaction. This finding is supported by other studies, where internet bandwidth, connectivity, availability of devices, downloadable resources, and mobile data connection were the key challenges to students' satisfaction on e-learning. ${ }^{32,33}$ Furthermore, our students suggested that efforts should be made from stakeholders regarding the provision of cost-effective, high-speed data services from telecommunication service providers and unlimited time in Zoom sessions to reduce distractions during online learning.

Majority of our students were satisfied with the prompt response from the concerned faculties and department via internet and content of the classes. The efficiency and effectiveness in delivering the e-learning based components of a course is one of the most critical factors to students' acceptance and success of the learning process. ${ }^{34}$ Online learning in medical education is very challenging because of the fact that the students have to learn and work directly with the patients (especially for the practical part). There are suggestions that some portion of practical/clinical classes be started through demonstration and presentation of related cases with simulation. It is evident in various studies that course materials prepared by instructors considering students' learning styles and learning methodology impacts the greatest in learner's satisfaction. ${ }^{35,36}$

Our findings indicated that the four domains under consideration: learners dimension, instructors' characteristics, technological characteristics and course management and coordination all had positive relationship with the overall satisfaction towards online learning, with learners' dimension being the strongest predictor where 
the findings are supported by other studies. ${ }^{37,38}$ In our study, female students had better satisfaction to the online learning. Evidences have been variable, with reports of no significant association between satisfaction and gender to female gender being a strong predictor of satisfaction in online learning. ${ }^{39,40}$ It has been suggested that women are oriented to openness for other's proposals, willing to cooperate and prefer working in groups while men are more likely to solve problems on their own. ${ }^{40}$ The variation however, can be due to the cultural differences across various countries.

This research adds value to the existing literature, through detailed analysis of students' satisfaction towards elearning during the times of COVID-19 pandemic. It also provides some important practical insights into how satisfaction and adherence to online learning be achieved in developing countries such as Nepal. Various factors need to be considered for successful implementation of e- learning environment. Firstly, the e-learning system designers need to make the system simple and user-friendly. Secondly, the policy makers need to adopt new education policies and regulations to promote e-learning system among students and instructors in order to facilitate gradual transition from traditional learning to e-learning. These factors, if positively entertained, will result in the growth of online education in our country in the coming decade. Our study has certain limitations. The subjects of this study were from only one college, this is a threat to the external validity. This study could have yielded better results if a more diverse group of respondents had been reached.

\section{CONCLUSION}

Educational institutions in our county have recently adopted online learning to carry forward the education activities during this COVID-19 pandemic. Student's satisfaction is an important factor for successful e- learning adoption and effective outcome. Our study presents that more than half of the students are satisfied with online learning. Learning domains such as learners' dimension, technological characteristics, instructors' characteristics and course management and coordination are significantly associated with students overall satisfaction towards online learning. Gender, internet modality as WIFI and learners dimension score tends to influence more on the learners' satisfaction towards online learning. These factors need to be considered in unison while designing online learning program in order to increase the adoption and satisfaction rate among the students.

\section{ACKNOWLEDGEMENT}

The authors acknowledge the support obtained from personnel from IT Department of the Chitwan Medical College (CMC).

\section{REFERENCES}

1. World Health Organization. Health topic: There is current outbreak of Coronavirus (COVID-19) disease. 2020.

2. The Kathmandu Post. Government extends lockdown until May 18. 2020, May 6.

3. Samarasekera DD, Goh DL, Lau TC. Medical school approach to manage the current COVID-19 crisis. Academic Medicine. 2020 Aug 1;95(8):1126-7.

4. Kaur N, Dwivedi D, Arora J, Gandhi A. Study of the effectiveness of e-learning to conventional teaching in medical undergraduates amid COVID-19 pandemic. National Journal of Physiology, Pharmacy and Pharmacology. 2020;10(7):1.

5. Bączek M, Zagańczyk-Bączek $M$, Szpringer $M$, Jaroszyński $A$, Wożakowska-Kapłon B. Students' perception of online learning during the COVID-19 pandemic: A survey study of Polish medical students.

6. Cidral WA, Oliveira T, Di Felice M, Aparicio M. E-learning success determinants: Brazilian empirical study. Computers \& Education. 2018 Jul 1;122:273-90.

7. Pei L, Wu H. Does online learning work better than offline learning in undergraduate medical education? A systematic review and metaanalysis. Medical Education Online. 2019 Jan 1;24(1):1666538.

8. Dawadi S, Giri R, Simkhada P. Impact of COVID-19 on the Education Sector in Nepal: Challenges and Coping Strategies.

9. Zhao J, Xiao H, Li Y, Wen D, Xu P, Fu Y, et al. Experience of Massive Distance Online Education for Medical Colleges and Universities in China to Counter the COVID-19 Pandemic.2020.

10. Han H, Resch DS, Kovach RA. Educational technology in medical education. Teaching and Learning in Medicine. 2013 Jan 1;25(sup1):S39-43.

11. Rahamat RA, Shah PM, Din RO, Puteh SN, Aziz JA, Norman HE, Embi MA. Measuring learners' perceived satisfaction towards e-learning material and environment. WSEAS Transactions on Advances in Engineering Education. 2012;9(3):72-83.

12. Chow WS, Shi S. Investigating students' satisfaction and continuance intention toward e-learning: An Extension of the expectationconfirmation model. Procedia-Social and Behavioral Sciences. 2014 Aug 25;141:1145-9.

13. Al-Rahmi WM, Othman MS, Yusuf LM. Exploring the factors that affect student satisfaction through using e-learning in Malaysian higher education institutions. Mediterranean Journal of Social Sciences. 2015 Jul 3;6(4):299.

14. Biner PM. The development of an instrument to measure student attitudes toward televised courses. American Journal of Distance Education. 1993 Jan 1;7(1):62-73.

15. Wang YS. Assessment of learner satisfaction with asynchronous electronic learning systems. Information \& Management. 2003 Oct 1;41(1):75-86.

16. Bawa P. Retention in online courses: Exploring issues and solutions-A literature review. Sage Open. 2016 Jan 5;6(1):2158244015621777.

17. Seada AI, Mostafa MF. Students' Satisfaction and Barriers of E-Learning Course among Nursing Students, Mansoura University. IDOSI Publications. 2017;3 (3): 170-178, 2017. 
18. Singh A, Min AK. Digital lectures for learning gross anatomy: A study of their efficacy. Korean Journal of Medical Education. 2017 Mar;29(1):27.

19. George PP, Papachristou N, Belisario JM, Wang W, Wark PA, Cotic Z, Rasmussen K, Sluiter R, Riboli-Sasco E, Car LT, Musulanov EM. Online eLearning for undergraduates in health professions: a systematic review of the impact on knowledge, skills, attitudes and satisfaction. Journal of Global Health. 2014 Jun;4(1).

20. Pourghaznein T, Sabeghi H, Shariatinejad K. Effects of e-learning, lectures, and role playing on nursing students' knowledge acquisition, retention and satisfaction. Medical Journal of the Islamic Republic of Iran. 2015;29:162.

21. Abbasi S, Ayoob T, Malik A, Memon SI. Perceptions of students regarding E-learning during Covid-19 at a private medical college. Pakistan Journal of Medical Sciences. 2020 May 9;36(COVID19-S4).

22. Al-Fahad FN. The Learners' Satisfaction toward Online E-Learning Implemented in the College of Applied Studies and Community Service, King Saud University, Saudi Arabia: Can E-Learning Replace the Conventional System of Education? Turkish Online Journal of Distance Education. 2010 Apr;11(2):61-72.

23. Johnson $A M$, Jacovina $M E$, Russell DG, Soto CM. Challenges and solutions when using technologies in the classroom. ERIC Clearinghouse. 2016 Jun 17.

24. Bahramnezhad F, Asgari P, Ghiyasvandian S, Shiri M, Bahramnezhad F. The Learners' Satisfaction of E-learning: A Review. American Journal of Educational Research. 2016;4(4):347-52. [DOI]

25. Unwin T, Kleessen B, Hollow D, Williams JB, Oloo LM, Alwala J, et al. Digital learning management systems in Africa: myths and realities. Open Learning: The Journal of Open, Distance and e-Learning. 2010 Feb 1;25(1):5-23.

26. Liaw SS, Huang HM, Chen GD. Surveying instructor and learner attitudes toward e-learning. Computers \& Education. 2007 Dec 1;49(4):1066-80.

27. Sultana T, Khan RH. Investigating University Students' Satisfaction on Online Class: Bangladesh Perspective. Bangladesh Educational Journal. 2019 Dec:23.

28. Goh C, Leong C, Kasmin K, Hii P, Tan O. Students' experiences, learning outcomes and satisfaction in e-learning. Journal of E-learning and Knowledge Society. 2017 May 29;13(2).
29. Adas D, Shmais WA. Students' perceptions towards blended learning environment using the OCC. An-Najah University Journal for Research-Humanities. 2011 25(6): 1681-1710.

30. Mirza AA, Al-Abdulkareem M. Models of e-learning adopted in the Middle East. Applied Computing and Informatics. 2011 Jul 1;9(2): 8393.

31. Tarus JK, Gichoya D, Muumbo A. Challenges of implementing e-learning in Kenya: A case of Kenyan public universities. Internationa Review of Research in Open and Distributed Learning. 2015;16(1): 120-41.

32. Mässing C. Success Factors and Challenges for E-learning Technologies in the Namibian Higher Education System: A case study of the University of Namibia.

33. Al-Azawei A, Parslow P, Lundqvist K. Barriers and opportunities of e-learning implementation in Iraq: A case of public universities. The International Review of Research in Open and Distributed Learning. 2016 Sep 26;17(5).

34. Keržič D, Tomaževič N, Aristovnik A, Umek L. Exploring critical factors of the perceived usefulness of blended learning for higher education students. PLOS ONE. 2019 Nov 21;14(11):e0223767.

35. Swan K. Learning effectiveness online: What the research tells us. Elements of quality online education, practice and direction. 2003;4(1):13-47

36. Battalio J. Success in distance education: Do learning styles and multiple formats matter?. The American Journal of Distance Education. 2009 May 19;23(2):71-87.

37. Riaz A, Riaz A, Hussain M. Students' acceptance and commitment to e-learning: Evidence from Pakistan. Journal of Educational and Social Research. 2011 Dec 1;1(5):21.

38. Nadia AY, Iqbal S. Student Satisfaction with e-Learning achieved in Pakistan. Asian Journal of Distance Education. 2011 Jan 1;9(2):26-31.

39. Topal AD. Examination of University Students' Level of Satisfaction and Readiness for E-Courses and the Relationship between Them. European Journal of Contemporary Education. 2016;15(1):7-23.

40. González-Gómez F, Guardiola J, Rodríguez ÓM, Alonso MÁ. Gender differences in e-learning satisfaction. Computers \& Education. 2012 Jan 1;58(1):283-90. 